\title{
Behavioral parameters and surface temperatures of feed chicken with different leves vitamin $E^{1}$
}

\section{Parâmetros comportamentais e temperaturas de superfície de frangos alimentados com diferentes níveis de vitamina $\mathrm{E}$}

Latóya de Sousa Bezerra2*; Roberta Gomes Marçal Vieira Vaz; Mônica Calixto da Silva4; Danilo Vargas Gonçalves Vieira3; Luiz Fernando Teixeira Albino5; Hérica de Araujo Costa2; Mayara da Cruz Ribeiro6; Josimar Santos de Almeida7; Jerry Kleube Felix Monteiro Junior ${ }^{8}$; Magna Ferreira de Oliveira ${ }^{8}$

\section{Highlights}

The different levels of vitamin E did not affect the behavior of the birds.

The different levels of vitamin $\mathrm{E}$ did not affect the surface temperatures of broilers.

The amounts of vitamin E did not affect the feed intake of broilers.

\section{Abstract}

The objective of this study was to evaluate the behavioural parameters and surface temperatures of broilers fed different vitamin E levels. A total of 240 male, day-old Cobb $500^{\circledR}$ broiler chicks were raised until the seventh day of life, according to the recommendations for the strain, receiving feed with only $50 \%$ of vitamin $\mathrm{E}$ requirements. At eight days of age, the birds were weighed and standardised, and the treatments distributed in a completely randomised design with four treatments (50,100, 150 and $200 \%$ of vitamin E requirements) and six replicates of ten birds per experimental unit. The variables evaluated were the behavioural parameters of the birds (eating, drinking, idleness and other activities) and the feed intake within 24 hours as well as the maximum and minimum surface temperatures, and thermal amplitudes at the end of each life cycle (21 and

1 Part of the first author's Master's Thesis.

2 Doctoral Students of the Graduate Program in Tropical Animal Science, Universidade Federal do Tocantins, UFT, Araguaína, TO, Brazil. E-mail: latoyanina@hotmail.com; hericaaraujocosta@gmail.com

3 Profs. Drs., Department of Animal Science, School of Veterinary Medicine and Animal Science, UFT, Araguaína, TO, Brazil. E-mail: betagmvvaz@yahoo.com.br; danilovargaszoo@hotmail.com

4 Profa Dra ${ }^{a}$ Department of Animal Science, Universidade Federal Rural do Amazonas, UFRA, Paragominas, PA, Brazil. E-mail: monicalixto_@hotmail.com

5 Prof. Dr., Department of Animal Science, School of Veterinary Medicine and Animal Science, Universidade Federal de Viçosa, UFV, Viçosa, MG, Brazil. E-mail: lalbino@ufv.com.

6 Dra in Tropical Animal Science, UFT, Araguaína, TO, Brazil. E-mail: mayzoo@hotmail.com

7 M.e in Tropical Animal Science, UFT, Araguaína, TO, Brazil. E-mail: almeidajs@mail.uft.edu.br

8 Students of the Master's Course of the Graduate Program in Tropical Animal Science, UFT, Araguaína, TO, Brazil. E-mail: jerryjunior00@hotmail.com; magnaferreira09@gmail.com

* Author for correspondence

Received: Apr. 20, 2021 - Approved: Sept. 23, 2021 
42 days). Vitamin E levels did not influence behavioural parameters or feed intake over 24 hours at 21 and 42 days of age. There was no interaction between vitamin E levels and maximum and minimum temperatures or thermal amplitudes. However, the maximum and minimum temperatures and thermal amplitudes were influenced by the morning and afternoon periods at 21 and 42 days of age. Dietary vitamin E levels did not influence the behavioural patterns of broilers at 21 and 42 days of age.

Key words: Alpha tocopherol. Thermal comfort. Thermographic image. Welfare.

\section{Resumo}

Objetivou-se avaliar os parâmetros comportamentais e as temperaturas superficiais de frangos de corte alimentados com diferentes níveis de vitamina E. Um total de 240 pintos de corte machos Cobb $500^{\circledR}$ de um dia foram criados até o sétimo dia de vida, de acordo com a recomendação da linhagem e recebendo ração com apenas $50 \%$ das necessidades de vitamina E. Aos oito dias de idade, as aves foram pesadas e padronizadas e os tratamentos distribuídos em delineamento inteiramente casualizado com quatro tratamentos (50, 100, 150 e 200\% das necessidades de vitamina E) e seis repetições de dez aves por unidade experimental. As variáveis avaliadas foram os parâmetros comportamentais das aves (comer, beber, ociosidade e outras atividades) e o consumo de ração em 24 horas, bem como as temperaturas superficiais máximas, mínimas e amplitudes térmicas ao final de cada ciclo de vida (21 e 42 dias). Os níveis de vitamina E não influenciaram os parâmetros comportamentais e o consumo de ração ao longo de 24 horas aos 21 e 42 dias de idade. Não houve interação entre os níveis de vitamina E para temperaturas máximas e mínimas e amplitudes térmicas. Porém, as temperaturas máximas e mínimas e amplitudes térmicas foram influenciadas pelos períodos da manhã e da tarde aos 21 e 42 dias de idade. Os níveis de vitamina E na dieta não influenciaram os padrões de comportamento de frangos de corte aos 21 e 42 dias de idade.

Palavras-chave: Alfa-tocoferol. Bem-estar. Conforto térmico. Imagem termográfica.

\section{Introduction}

Heat stress is a cause of concern in broiler breeding in tropical countries, such as Brazil, as it can directly affect the natural behaviour of birds, reducing feed consumption, feed efficiency, growth, mortality and other factors, important characteristics for the success of an activity that had its highest production rates in recent years (Carvalho et al., 2013; Lopes, Ribeiro, \& Lima, 2015a). Broiler chickens are animals that need an environment within the thermal comfort zone since they do not have an efficient thermoregulatory system. The regulation of body temperature requires a high expenditure of energy, causing losses to the performance of the birds, producer and industry (Dalólio, Albino, Lima, Silva, \& Moreira, 2015; Lopes et al., 2015b).

Therefore, the environment to which birds are subjected is considered a key factor for success and consequently, from an economic point of view, is capable of generating gains or losses. The expense to maintain homeothermia can reach $80 \%$ of the total energy ingested by the bird, leaving only $20 \%$ for production. It is necessary to have knowledge of four important points to give the bird as much comfort as possible; these are the climate of the region, the physiology of the bird, and the ambience and typification of the 
system. Therefore, maintaining the thermal comfort of birds is a challenge (Abreu \& Abreu, 2011).

When subjected to heat stress, broilers tend to reduce feed consumption, increase water intake, downtime, respiratory rate, spread the wings from the body and activate mechanisms to try to lose heat, affecting behaviour and consequently, their productive performance (Albuquerque et al., 2017).

Thus, management, facilityand nutrition strategies have been developed to minimise the deleterious effects of heat. Among these, the use of functional micronutrients, such as vitamin $\mathrm{E}$, has been mentioned. Vitamin $\mathrm{E}$, due to its antioxidant action, may influence the stabilisation of polyunsaturated fatty acids, which could improve meat quality, feed intake, performance and the immunity of birds raised under high temperatures (Dalólio et al., 2015).

According to Diniz and Mello (2014), stress caused to broilers by high temperatures directly influences carcass fat and protein deposition, besides affecting the final quality of the product. The use of functional nutrients in diets, including vitamin $\mathrm{E}$, can be a way to minimise these effects without impairing the productive performance and changing the birds' natural behaviour (Harsini, Habibiyan, Moeini, \& Abdolmohammadi, 2012). Therefore, the objective of this study was to evaluate the behavioural parameters and surface temperatures of broilers fed different levels of vitamin $\mathrm{E}$.

\section{Material and Methods}

The experiment was conducted at the Poultry Sector of the School of Veterinary Medicine and Animal Science of the Federal University of Tocantins, located in Araguaína -TO, latitude $07^{\circ} 11^{\prime} 27^{\prime \prime} \mathrm{S}$, longitude $48^{\circ} 12^{\prime}$ $25^{\prime \prime} \mathrm{W}$ and altitude of $236 \mathrm{~m}$, from March 30 to May 11, 2018, and was executed according to the ethical standards established by the Law of Procedures for the Use of Animals, as determined by the Animal Ethics Commission of the Federal University of Tocantins (CEUAUFT), with protocol $n^{\circ} 23101.004458 .2017-$ 51.

A total of 240 one-day-old male Cobb $500^{\circledR}$ broiler chicks were bred to the seventh day according to the strain's recommendations and fed a diet containing only $50 \%$ of the vitamin $\mathrm{E}$ (alpha-tocopherol) requirements. At eight days of age, the birds, with mean weights of $187.3 \mathrm{~g} \pm 14.47 \mathrm{~g}$, were standardized and the treatments were distributed in a completely randomized design with four treatments (50, 100,150 and $200 \%$ of the vitamin requirements $E$ (alpha-tocopherol) according to the recommendations of Rostagno et al (2017), Table 1) and six replicates with ten birds per experimental unit.

\section{Table 1}

Vitamin E levels in diets for broilers at different stages of breeding

\begin{tabular}{ccccc}
\multirow{2}{*}{ Breeding stage } & \multicolumn{4}{c}{ Treatment $(\mathrm{g} / 100 \mathrm{~kg}$ feed) } \\
\cline { 2 - 5 } & $50 \%$ & $100 \%^{\mathrm{a}}$ & $150 \%$ & $200 \%$ \\
\hline $8-21$ days & 2.29 & 4.58 & 6.87 & 9.16 \\
$22-42$ days & 1.80 & 3.61 & 5.41 & 7.22
\end{tabular}

${ }^{\text {a }}$ Requirements recommended by Rostagno et al. (2017). 
The birds were housed in an experimental shed, covered with sandwich tile, that had a concrete floor, and side curtains. The birds were managed according to their behavior, and they were provided with 24 boxes of $2.0 \mathrm{~m} 2$, with tubular feeders and pendular drinkers. Filling of the feeders, cleaning, and refilling drinkers was carried out twice a day, allowing free access to water and feed throughout the experimental period.

The birds were artificially heated, until the 14th day of life, using incandescent lamps $(60 \mathrm{~W})$ installed inside all the boxes. The light program adopted was continuous (24 hours of natural + artificial light). During the experimental period, the environmental conditions inside the facilities were monitored and recorded every 30 minutes using $\mathrm{HOBO}$ ware OnSet ${ }^{\circledR}$ Version 3.4.1 data loggers, placed in the middle of the pits, making it possible to obtain the mean values for air temperature, relative air humidity and black globe temperature; these values being converted into the ITGU (Globe and Humidity Temperature Index), according to Buffington et al. (1981) (Table 2).

Experimental diets were calculated considering the nutritional requirements of higher average performance chickens, according to the recommendations of Rostagno et al. (2017), in the stages 1-7, 8-21, and 22-42 days of age (Table 3).

The variables evaluated were the behavioral parameters of the birds (eating, drinking, idleness, and other activities), the surface temperatures of the broilers, and the feed intake in a 24 hours period at the end of each production cycle, 21 and 42 days of age.

\section{Table 2}

Average values of temperature $\left({ }^{\circ} \mathrm{C}\right)$, relative humidity $(\mathrm{RH})$ and Globe Temperature and Humidity Index (GTHI)

\begin{tabular}{|cccc|}
\hline \multicolumn{2}{c}{21 days old } & ITGU \\
\hline Period & Temperature ${ }^{\circ} \mathrm{C}$ & UR (\%) & 77.6 \\
\hline Everning & 27.4 & 76.1 & 82.3 \\
\hline Period & 32.7 & 50.1 & ITGU \\
\hline Morning & Temperature ${ }^{\circ} \mathrm{C}$ & 42 days old & \\
\hline Evening & 24.2 & UR (\%) & 74.1 \\
\hline
\end{tabular}


Table 3

Composition of the diets for broiler chickens in different breeding phases (days)

\begin{tabular}{|c|c|c|c|}
\hline \multirow{2}{*}{ Ingredients (g/kg) } & \multicolumn{3}{|c|}{ Breeding phase (days) } \\
\hline & 1 to 7 & 8 to 21 & 22 to 42 \\
\hline Corn (7.88\%) & 561.00 & 581.10 & 627.00 \\
\hline Soybean meal (45\%) & 370.90 & 344.40 & 305.90 \\
\hline Dicalcium phosphate & 19.00 & 16.70 & 11.70 \\
\hline Soy oil & 21.20 & 30.90 & 34.60 \\
\hline Limestone & 11.20 & 9.90 & 8.30 \\
\hline Common salt & 5.00 & 5.00 & 4.40 \\
\hline DL-Methionine & 3.80 & 3.80 & 2.40 \\
\hline L-Lysine & 3.10 & 3.30 & 2.00 \\
\hline L-Threonine & 1.30 & 1.50 & 0.50 \\
\hline Mineral supplement & 1.00 & 1.00 & 1.00 \\
\hline Vitamin supplement & 1.00 & 1.00 & 1.00 \\
\hline Choline chloride & 0.90 & 0.80 & 0.60 \\
\hline Salinomycin & 0.50 & 0.50 & 0.50 \\
\hline Butylated hydroxytoluene & 0.10 & 0.10 & 0.10 \\
\hline Total & 1000.00 & 1000.00 & 1000.00 \\
\hline \multicolumn{4}{|c|}{ Calculated nutritional composition } \\
\hline Metabolizable energy (kcal/kg) & 2975 & 3050 & 3175 \\
\hline Crude protein $(\mathrm{g} / \mathrm{kg})$ & 222.00 & 208.00 & 195.70 \\
\hline Calcium (g/kg) & 9.70 & 8.80 & 6.90 \\
\hline Available phosphorus (g/kg) & 4.60 & 4.20 & 3.30 \\
\hline Digestible lysine (g/kg) & 13.00 & 12.50 & 10.70 \\
\hline Methionine + digestible cystine $(\mathrm{g} / \mathrm{kg})$ & 9.60 & 9.30 & 7.90 \\
\hline Digestible methionine $(\mathrm{g} / \mathrm{kg})$ & 6.50 & 6.50 & 5.00 \\
\hline Digestive threonine (g/kg) & 8.60 & 8.30 & 7.00 \\
\hline Sodium $(g / k g)$ & 2.20 & 2.20 & 2.00 \\
\hline
\end{tabular}

a Recommendation and vitamin supplement composition per $\mathrm{kg}$ of diet formulated at the $100 \%$ level according to Rostagno et al. (2017).

${ }^{\mathrm{b}}$ Mineral supplement (kg/t feed): Broiler: pre-initial, 1.25; initial, 1.10; growth I (22-35 days), 1.00. Supplementation composition (mg/kg feed) in the growth phase: copper, 10; iron, 50; iodine, 0.8; manganese, 65; selenium, 0.30; zinc, 60. c Vitamin (Vit.) supplement (kg/t feed): Broiler: pre-initial, 1.25; initial, 1.10; growth I (22-35 days), 1.00. Vit. A, 8,000.00 IU; Vit. D, 1,600.00 IU; Vit. K, 1400 mg; Vit. B1, 1,200 mg; Vit. B2, 4,000 mg; nicotinic acid, 28.00 mg; pantothenic acid, 9,600 mg; Vit. B6, 1900 mg; Vit. B12, 10 mg; folic acid, 560 mg; biotin, 56 mg. 
To determine the behavioral parameters, two birds from each experimental unit were selected and marked on the back with non-toxic dyes (Figure 1). Observations were made by filming for 10 minutes in each experimental unit, totaling 60 minutes of filming per treatment in the comfort (07:00-09: $00 \mathrm{~h})$ and stress (13:00-16: 00h) periods at the end of the study each of the birds' life cycle (21st and 42nd day).

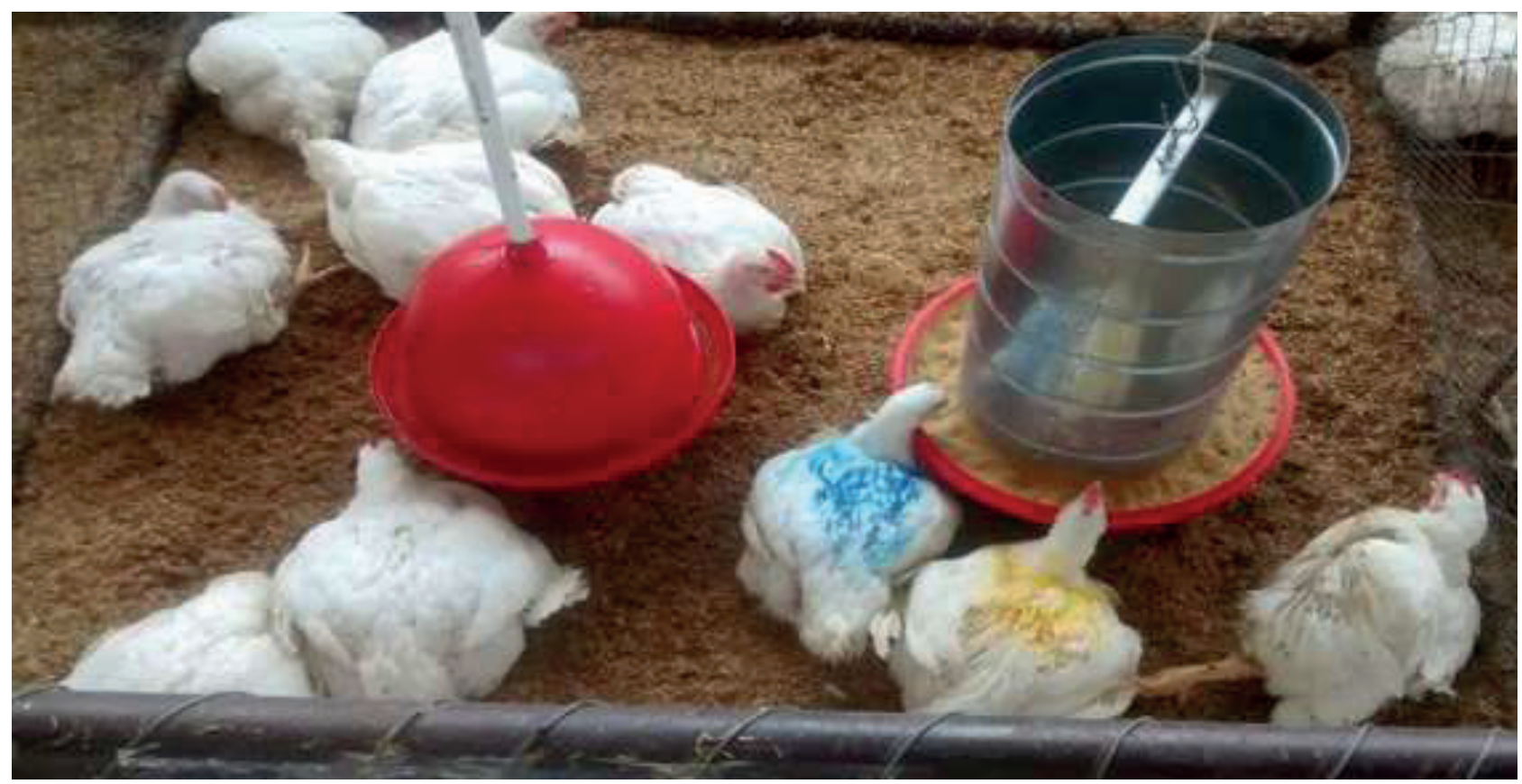

Figure 1. Image of birds marked for behavioral evaluation.

To evaluate feed intake over the 24hour period, the feeders were weighed at 07:00, 10:00, 13:00, 16:00, 19:00, and 07:00. After filming ended in each period, thermographic photos were taken with a FLIR E60 ${ }^{\circledR}$ camera, 1 $m$ from the birds (Figure 2). Behavioral patterns were adapted according to the methodology proposed by Rudkin and Stewart (2003), taking into account the activities developed by each bird (Table 4). 

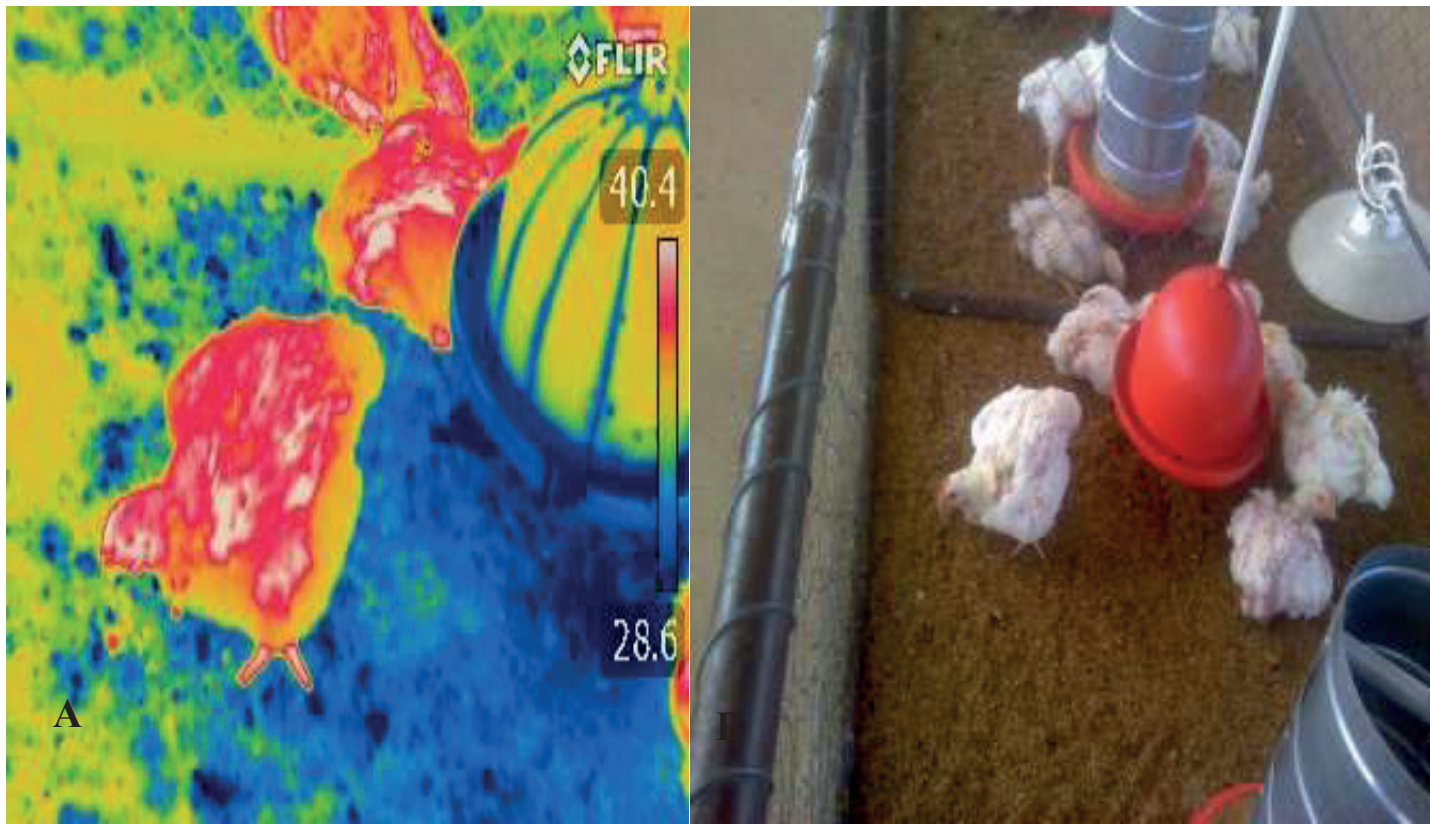

Figure 2. Thermographic photo $(A)$ and common photo $(B)$ of broilers.

\section{Table 4}

\section{Behavioral parameters of broilers}

\section{Behavior Behavior Description}

Eating When the bird is feeding, a behavior characterized by the bird having its head in the feeder

Drinking When the bird is drinking water, characterized by the bird pecking at the nipple drinker

\section{Other activities}

Investigating Non-aggressive behavior, characterized by the bird investigating its own feathers with Feathers its beak or investigating the feathers of other birds

Shower Characteristic behavior of birds, which involves a sequence of shearing and throwing "sand" over its body, in addition to quick movements of shaking the feathers
Aggressive
behavior
Characteristic behavior of birds that are out of their welfare state

Comfort movements

Behaviors exhibited by birds when they were in conditions of comfort and welfare; comfort movements are behaviors such as flapping and stretching the wings and shaking the feathers

Scratching Behavior characterized by the bird exploring its territory with its feet and beak;

Behavior related to the condition of establishing dominance in the group or stress

Aggressiveness conditions, usually characterized by rapid and strong pecks at places such as the crest and other parts of the head

\section{Idleness}

Sitting Behavior characterized by the bird sitting on the bed or substrate where it was

Stop Behavior characterized by the bird showing no movement or apparently not fitting into any of the previous behaviors 
After filming, the images were analyzed, and the average percentages of the times of each behavior were calculated. The thermographic images were evaluated with the aid of the FLIR Tools program, in which a rectangular design was made in the left dorsal region of each bird, to obtain the maximum and minimum surface temperatures as well as the thermal amplitudes (Figure 3).

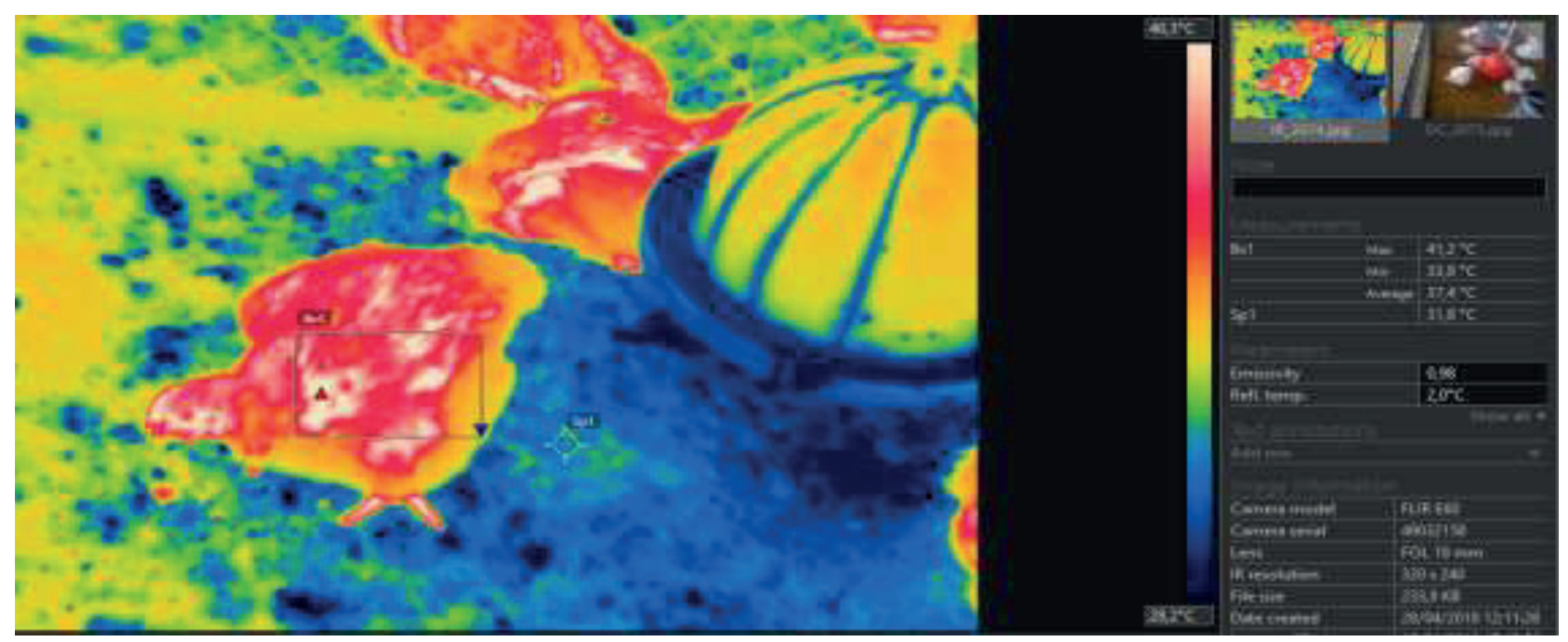

Figure 3. Thermo-image used to evaluate surface temperatures.

Data were submitted to normality (Cramer Von Mises) and homoscedasticity (Levene's) tests. These assumptions being satisfied, the surface temperatures averages were evaluated in a $2 \times 4$ factorial arrangement (two periods and four levels of vitamin E), and then the behavioral percentages and feed intakes were submitted to an analysis of variance. Additionally, the treatment means were compared by theTukey test, considering a significance level of $5 \%$ or less. Statistical analyses were performed with the aid of SISVAR Software.

\section{Results and Discussion}

Increasing levels of vitamin $E$ in diets did not influence $(P>0.05)$ behavioural parameters such as eating (EAT), drinking (DRI), idleness (IDL) and other activities (OAT) of broiler chickens at 21 days of age (Figure 4). 


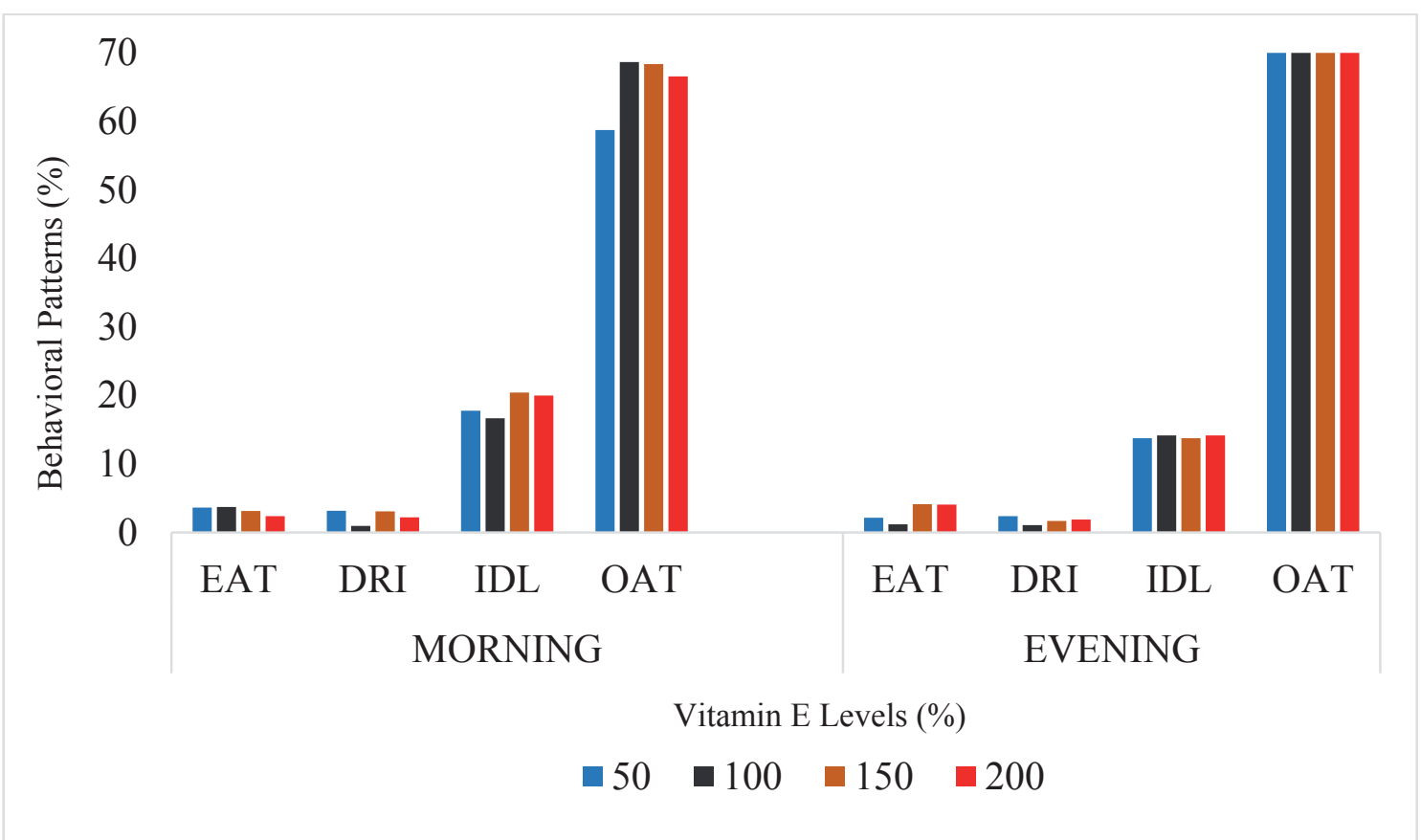

Figure 4. Behavioral patterns eating (EAT), drinking (DRI), idleness (IDL) and other activities (OAT) of broilers (morning and afternoon) fed with different levels of vitamin $E$ at 21 days of age.

The behaviour of birds is directly related to the physiological and environmental factors to which they are subject, thus reflecting well-being or stress. When exposed to unfavourable temperatures, birds behave differently. The first signs of change in the behaviour of chickens are a reduction in feed consumption and an increase in water consumption, in addition to compromising othervariables (Carvalho etal., 2013). However, these behaviours were not observed in the present study. Even with an average ambient temperature of $30.5{ }^{\circ} \mathrm{C}$, the birds did not change their behaviour patterns, regardless of vitamin $\mathrm{E}$ levels. This may be due to the fact that they had adapted to the antioxidant effects of vitamin $E$, which is classified as a functional nutrient, and had been raised under the same environmental conditions.

Increasing levels of vitamin $\mathrm{E}$ did not influence $(P>0.05)$ the behavioural parameters, including eating (EAT), drinking (DRI), idleness (IDL) and other activities (OAT) of broilers at 42 days of age (Figure 5). 


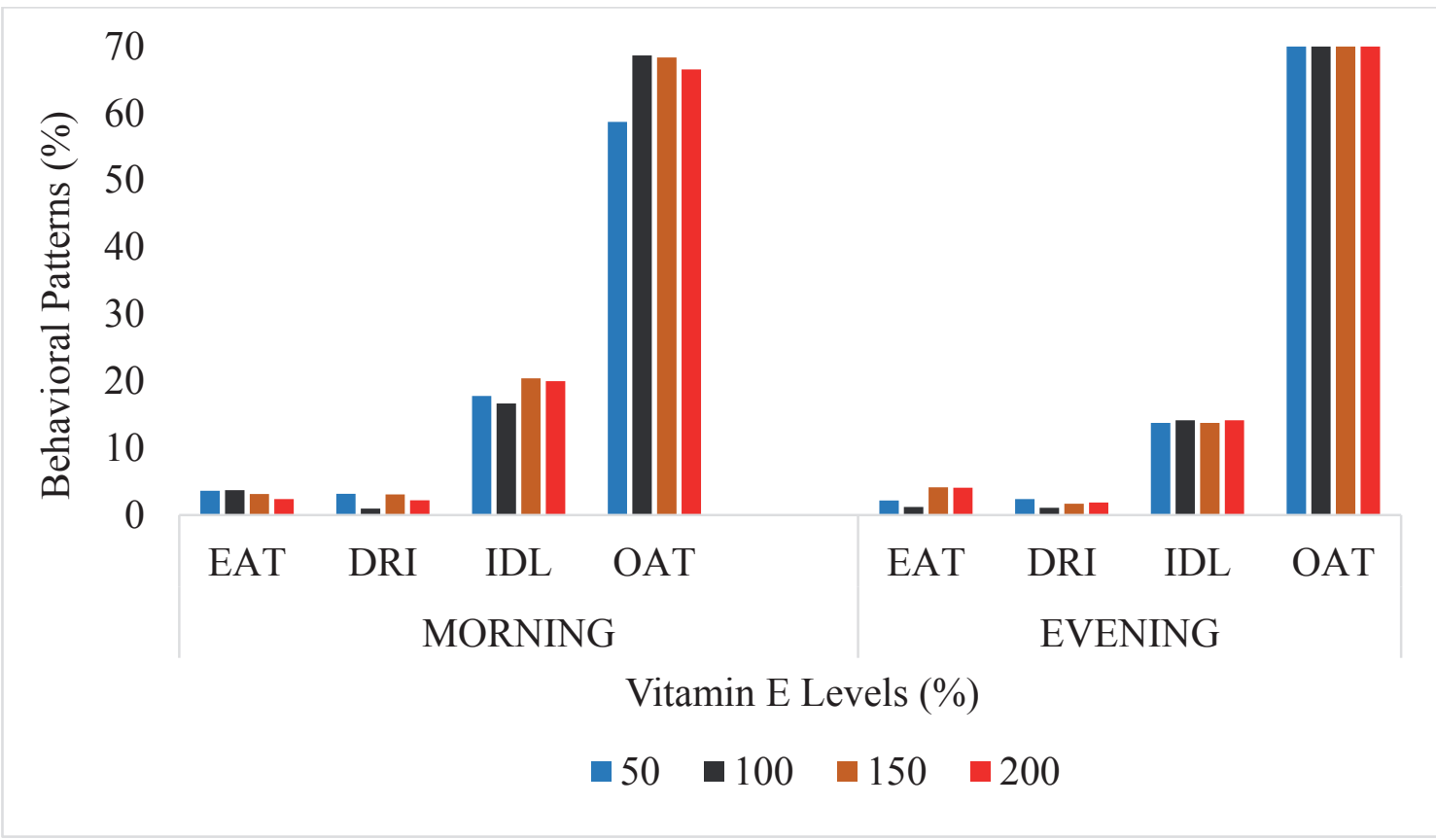

Figure 5. Behavioral patterns of eating (EAT), drinking (DRI), idleness (IDL) and other activities (OAT) of broilers (morning and afternoon) fed with different levels of vitamin $E$ at 42 days of age.

Divergent results were found by Barbosa, Mouro, Branco and Oliveira (2018), who evaluated the behavioural parameters and welfare of broiler chickens submitted to three temperatures, comfort, moderate heat and intense heat, and concluded that a temperature of $4{ }^{\circ} \mathrm{C}$ above the comfort zone had little influence on the behaviour of the birds at 7, 14 and 21 days. However, temperatures 5-7 ${ }^{\circ} \mathrm{C}$ above the comfort zone considerably reduced locomotion activities, which affected the welfare of birds at 39 days of age.

There was no interaction between dietary vitamin $E$ levels $(P>0.05)$ for maximum and minimum surface temperatures and the temperature range in the morning and afternoon. However, the maximum and minimum temperatures and thermal amplitudes were influenced $(P<0.05)$ by the periods with lower temperatures for the morning (Table 5).

Variations in environmental conditions can directly influence surface temperatures, as birds are in constant heat exchange with the environment. Broilers are animals that can maintain body temperature within a narrow range of temperature variation, and when subjected to temperatures outside the thermal comfort zone, lose or gain heat from the environment, changing their body and surface temperatures (Nascimento, Pereira, Näas, \& Rodrigues, 2011; Schiassi et al., 2015).

From the value of the Black Globe Temperature Humidity Index (BGHI) on the day of the surface temperature assessment, it can be inferred that the birds were under thermal stress, as, according to the recommendations of Oliveira et al. (2006), the BGHI value 
considered as comfortable for the third week of age is around 74.9, which was higher than the value found for the morning and lower than that of the afternoon, 74.1 and 81.1, respectively (Table 2).

\section{Table 5}

Maximum and minimum surface temperatures $\left({ }^{\circ} \mathrm{C}\right)$ and thermal amplitude $\left({ }^{\circ} \mathrm{C}\right)$ values of broilers at 21 days, fed with different levels of vitamin $E$

\begin{tabular}{|c|c|c|c|c|c|c|c|c|c|}
\hline \multicolumn{10}{|c|}{ Maximum temperature $\left({ }^{\circ} \mathrm{C}\right)$} \\
\hline \multirow{2}{*}{ Period } & \multicolumn{4}{|c|}{ Levels of inclusion of vitamin E (\%) } & \multirow{2}{*}{ Average } & \multicolumn{3}{|c|}{$\mathrm{P}$} & \multirow{2}{*}{$\begin{array}{l}\text { CV } \\
(\%)\end{array}$} \\
\hline & 50 & 100 & 150 & 200 & & Per. & Vit E. & Per. $\times$ Vit E. & \\
\hline Morning & 40.72 & 40.68 & 40.32 & 40.62 & $40.58 \mathrm{~B}$ & & & & \\
\hline Evening & 41.12 & 41.03 & 41.12 & 40.75 & $41.00 \mathrm{~A}$ & 0.0042 & 0.5871 & 0.3991 & 1.18 \\
\hline Average & 40.92 & 40.85 & 40.72 & 40.68 & 40.79 & & & & \\
\hline \multicolumn{10}{|c|}{ Minimum temperature $\left({ }^{\circ} \mathrm{C}\right)$} \\
\hline \multirow{2}{*}{ Period } & \multicolumn{4}{|c|}{ Levels of inclusion of vitamin E (\%) } & \multirow{2}{*}{ Average } & \multicolumn{3}{|c|}{$\mathrm{P}$} & \multirow{2}{*}{$\begin{array}{l}\text { CV } \\
\text { (\%) }\end{array}$} \\
\hline & 50 & 100 & 150 & 200 & & Per. & Vit E. & Per. $\times$ Vit E. & \\
\hline Morning & 32.5 & 32.43 & 32.32 & 32.75 & $32.50 \mathrm{~B}$ & & & & \\
\hline Evening & 33.65 & 34.67 & 34.30 & 33.22 & $33.96 \mathrm{~A}$ & 0.001 & 0.6140 & 0.2202 & 3.40 \\
\hline Average & 33.08 & 33.55 & 33.31 & 32.98 & 33.23 & & & & \\
\hline \multicolumn{10}{|c|}{ Thermal range $\left({ }^{\circ} \mathrm{C}\right)$} \\
\hline \multirow{2}{*}{ Period } & \multicolumn{4}{|c|}{ Levels of inclusion of vitamin E (\%) } & \multirow{2}{*}{ Average } & \multicolumn{3}{|c|}{$\mathrm{P}$} & \multirow{2}{*}{$\begin{array}{l}\text { CV } \\
\text { (\%) }\end{array}$} \\
\hline & 50 & 100 & 150 & 200 & & Per. & Vit E. & Per. $\times$ Vit E. & \\
\hline Morning & 8.22 & 8.25 & 8.00 & 7.87 & $8.08 \mathrm{~A}$ & & & & \\
\hline Evening & 7.47 & 6.37 & 6.82 & 7.53 & $7.04 \mathrm{~B}$ & 0.0055 & 0.6884 & 0.4606 & 16.18 \\
\hline Average & 7.54 & 7.31 & 7.41 & 7.70 & 7.56 & & & & \\
\hline
\end{tabular}

Per = period; Vit $E .=$ vitamin $E ; P=$ Significant at $5 \%$ probability of error. Means with distinct letters in the same column differ significantly at $5 \%$ probability of error by the $F$ test.

There was no interaction between dietary vitamin $E$ levels $(P>0.05)$ for maximum and minimum temperatures and thermal amplitudes in the morning and afternoon. However, the maximum and minimum temperatures and thermal amplitudes were influenced $(P<0.05)$ by the period at 42 days of age, with lower temperatures for the morning (Table 6).

In the final phase of rearing, birds produce a higher amount of metabolic heat, which makes it necessary, in this phase, that the environment in which the birds are submitted is within the thermoneutral zone. This is because temperatures above those recommended by Habibian, Ghazi and Moeini (2015) of $24{ }^{\circ} \mathrm{C}$, may lead to a reduction of production and impairment of bird welfare.

Thus, environmental conditions within the rearing system directly influence the thermal comfort and welfare conditions, affecting the surface temperature of birds 
(Nazareno et al., 2009). The differences in maximum and minimum surface temperatures of birds in the morning and afternoon periods may be associated with the values of temperatures within the premises at these times, which were 27.3 and $33.3^{\circ} \mathrm{C}$, with GTHI values of 74.1 and 82.1 , respectively.

\section{Table 6}

Maximum surface temperatures $\left({ }^{\circ} \mathrm{C}\right)$, minimum surface temperatures $\left({ }^{\circ} \mathrm{C}\right)$, and temperature ranges $\left({ }^{\circ} \mathrm{C}\right)$ of broilers at $\mathbf{4 2}$ days, fed different levels of vitamin $E$

\begin{tabular}{|c|c|c|c|c|c|c|c|c|c|}
\hline \multicolumn{10}{|c|}{ Maximum temperature $\left({ }^{\circ} \mathrm{C}\right)$} \\
\hline \multirow{2}{*}{ Period } & \multicolumn{4}{|c|}{ Levels of inclusion of vitamin E (\%) } & \multirow{2}{*}{ Average } & \multicolumn{3}{|c|}{$\mathrm{P}$} & \multirow{2}{*}{$\begin{array}{l}\text { CV } \\
\text { (\%) }\end{array}$} \\
\hline & 50 & 100 & 150 & 200 & & Per. & Vit E. & Per. $\times$ Vit E. & \\
\hline Morning & 38.40 & 38.93 & 38.33 & 39.93 & $38.90 \mathrm{~B}$ & & & & \\
\hline Evening & 40.70 & 40.57 & 40.77 & 40.25 & $40.57 \mathrm{~A}$ & $<0.001$ & 0.7421 & 0.2216 & 3.43 \\
\hline Average & 39.55 & 39.75 & 39.55 & 40.09 & 39.74 & & & & \\
\hline \multicolumn{10}{|c|}{ Minimum temperature $\left({ }^{\circ} \mathrm{C}\right)$} \\
\hline \multirow{2}{*}{ Period } & \multicolumn{4}{|c|}{ Levels of inclusion of vitamin E (\%) } & \multirow{2}{*}{ Average } & \multicolumn{3}{|c|}{$\mathrm{P}$} & \multirow{2}{*}{$\begin{array}{l}\text { CV } \\
\text { (\%) }\end{array}$} \\
\hline & 50 & 100 & 150 & 200 & & Per. & Vit E. & Per. $\times$ Vit E. & \\
\hline Morning & 29.75 & 30.27 & 30.22 & 29.07 & 29.83 B & & & & \\
\hline Evening & 33.37 & 32.77 & 32.82 & 33.37 & $33.09 \mathrm{~A}$ & $<0.001$ & 0.9695 & 0.5949 & 6.03 \\
\hline Average & 31.57 & 31.53 & 31.52 & 31.23 & 31.46 & & & & \\
\hline \multicolumn{10}{|c|}{ Thermal range $\left({ }^{\circ} \mathrm{C}\right)$} \\
\hline \multirow{2}{*}{ Period } & \multicolumn{4}{|c|}{ Levels of inclusion of vitamin E (\%) } & \multirow{2}{*}{ Average } & \multicolumn{3}{|c|}{$\mathrm{P}$} & $\mathrm{CV}$ \\
\hline & 50 & 100 & 150 & 200 & & Per. & Vit E. & Per. $\times$ Vit E. & (\%) \\
\hline Morning & 8.65 & 8.65 & 8.12 & 10.87 & $9.07 \mathrm{~A}$ & & & & \\
\hline Evening & 7.32 & 7.82 & 7.97 & 6.87 & $7.07 \mathrm{~B}$ & 0.0075 & 0.6709 & 0.0967 & 23.47 \\
\hline Average & 7.97 & 8.22 & 8.04 & 8.87 & 8.27 & & & & \\
\hline
\end{tabular}

Per = period; $V$ it $E .=$ vitamin $E ; P=$ Significant at $5 \%$ probability of error. Means with distinct letters in the same column differ significantly at $5 \%$ probability of error by the $\mathrm{F}$ test.

Vitamin E levels in the diets did not influence $(P>0.05)$ the feed intake of broilers over 24 hours, from 07:00-19:00 and 19:0007:00, at 21 and 42 days of age (Table 7). 
Table 6

Maximum surface temperatures $\left({ }^{\circ} \mathrm{C}\right)$, minimum surface temperatures $\left({ }^{\circ} \mathrm{C}\right)$, and temperature ranges $\left({ }^{\circ} \mathrm{C}\right)$ of broilers at $\mathbf{4 2}$ days, fed different levels of vitamin $E$

\begin{tabular}{|c|c|c|c|c|c|c|}
\hline \multirow{2}{*}{ Schedules } & \multicolumn{4}{|c|}{ Vitamin E Levels (\%) } & \multirow{2}{*}{$\mathrm{CV}^{1}$} & \multirow{2}{*}{$P>F^{2}$} \\
\hline & 50 & 100 & 150 & 200 & & \\
\hline \multicolumn{7}{|c|}{21 days } \\
\hline 07:00-10:00 & 33.04 & 32.83 & 32.54 & 33.72 & 10.18 & 0.9383 \\
\hline 10:00-13:00 & 16.75 & 18.67 & 17.26 & 16.30 & 16.14 & 0.4995 \\
\hline 13:00-16:00 & 19.04 & 19.33 & 21.20 & 21.96 & 17.61 & 0.4389 \\
\hline $16: 00-19: 00$ & 15.25 & 17.33 & 15.80 & 14.06 & 13.97 & 0.1046 \\
\hline 19:00-07:00 & 103.88 & 100.17 & 99.24 & 101.56 & 7.08 & 0.7036 \\
\hline \multicolumn{7}{|c|}{42 days } \\
\hline 07:00-10:00 & 37.67 & 35.00 & 31.91 & 34.11 & 10.86 & 0.0977 \\
\hline 10:00-13:00 & 20.75 & 23.33 & 22.43 & 24.78 & 16.37 & 0.3271 \\
\hline 13:00-16:00 & 26.88 & 25.00 & 24.98 & 24.98 & 21.43 & 0.8983 \\
\hline $16: 00-19: 00$ & 17.17 & 17.83 & 17.48 & 18.45 & 17.07 & 0.8975 \\
\hline 19:00-07:00 & 120.70 & 122.50 & 117.20 & 114.19 & 7.31 & 0.3762 \\
\hline
\end{tabular}

${ }^{1}$ Coefficient of variation (\%).

When subjected to temperatures above the thermal comfort zone, birds tend to reduce feed intake to minimise metabolic heat production, due to the difficulty in exchanging heat with the environment, which consequently reduces productive performance (Brossi, Contreras-Castillo, Amazonas, \& Menten, 2009).

However, this behaviour was not observed, which may indicate that temperatures were not high enough to negatively interfere with this variable.

\section{Conclusion}

Vitamin E levels in the diets did not influence the behavioral patterns of broiler chickens at 21 and 42 days of age.

\section{Acknowledgment}

We wish to acknowledge the Coordination for the Improvement of Higher Education Personnel CAPES, for the scholarship grant, the Federal University of Tocantins -UFT, for the support and availability of the facilities, as well as Professor Luiz Fernando Albino and the companies Bonasa Alimentos and GRANFORTE for the supply of raw materials for the experiments.

\section{References}

Abreu, V. M. N., \& Abreu, P. G. de. (2011). Os desafios da ambiência sobre os sistemas de aves no Brasil. Revista Brasileira de Zootecnia, 40, 1-14. 
Albuquerque, D., Lopes, J. B., Ferraz, M. S., Ribeiro, M. N., Silva, S. R., Costa, M. S. E., Lopes, J. C. (2017). Vitamin E and organic selenium for broilers from 22 to 42 days old: performance and carcass traits. Anais da Academia Brasileira de Ciências, 89(2), 1259-1268. doi: 10.1590/00013765201720150709

Barbosa, Y. D. L., Moura, M. F., Branco, T., \& Oliveira, S. D. M. (2018). Análise de padrões comportamentais de frangos de corte em condições de estresse térmico por calor. Anais da Mostra de Estagiários e Bolsistas da EMBRAPA Informática Agropecuária, Campinas, SP, Brasil, 14..

Brossi, C., Contreras-Castillo, C. J., Amazonas, E. D. A., \& Menten, J. F. M. (2009). Estresse térmico durante o pré-abate em frangos de corte. Ciência Rural, 39(4), 12841293. doi: 10.1590/S0103-8478200900 5000039

Buffington, D. E., Collazo-Arocho, A., Canton, G. H., Pitt, D., Thatcher, W. W., \& Collier, R. J. (1981). Black globe-humidity index (BGHI) as comfort equation for dairy cows. Transactions of the ASAE, 24(3), 711-714. doi: $10.13031 / 2013.34325$

Carvalho, G. B. D., Lopes, J. B., Santos, N. P. D. S., Reis, N. B. D. N., Carvalho, W. F. D., Silva, S. F., \& Silva, S. M. D. (2013). Comportamento de frangos de corte criados em condições de estresse térmico alimentados com dietas contendo diferentes níveis de selênio. Revista Brasileira de Saúde e Produção Animal, 14(4), 785-797. doi: 10.1590/S1519-99402013000400012

Dalólio, F. S., Albino, L. F. T., Lima, H. J., Silva, J. N. D., \& Moreira, J. (2015). Heat stress and vitamin $\mathrm{E}$ in diets for broilers as a mitigating measure. Acta Scientiarum.
Animal Sciences, 37(4), 419-427. doi: 10. 4025/actascianimsci.v37i4.27456

Diniz, T. T., \& Mello, J. L. M. de. (2014). Efeito da temperatura ambiente e reutilização da cama na qualidade da carne de frangos de corte. Revista CES Medicina Veterinaria y Zootecnia, 9(2), 218-226.

Habibian, M., Ghazi, S., \& Moeini, M. M. (2015). Effects of dietary selenium and vitamin $E$ on growth performance, meat yield, and selenium content and lipid oxidation of breast meat of broilers reared under heat stress. Biological Trace Element Research, 169(1), 142-152. doi: 10.1007/ s12011-015-0404-6

Harsini, S. G., Habibiyan, M., Moeini, M. M., \& Abdolmohammadi, A. R. (2012). Effects of dietary selenium, vitamin $E_{\text {, and }}$ their combination on growth, serum metabolites, and antioxidant defense system in skeletal muscle of broilers under heat stress. Biological Trace Element Research, 148(3), 322-330. doi 10.1007/s12011-012-9374-0

Lopes, J. C. O., Ribeiro, M. N., \& Lima, V. B. S. (2015a). Estresse por calor em frangos de corte. Revista Eletrônica Nutri-Time, 12(6), 4478-4487.

Lopes, J. C. O., Figueirêdo, A. V. de, Lopes, J. B., Lima, D. C. P., Ribeiro, M. N., \& Sousa Lima, V. B. de. (2015b). Zinco e vitamina E em dietas para frangos de corte criados em estresse calórico. Revista Brasileira de Saúde e Produção Animal, 16(2), 350364. doi: 10.1590/S1519-994020150002 00010

Nascimento, G. R. D., Pereira, D. F., Näas, I. D. A., \& Rodrigues, L. H. (2011). Índice fuzzy de conforto térmico para frangos de corte. 
Engenharia Agrícola, 31(2), 219-229. doi: 10.1590/S0100-69162011000 200002

Nazareno, A. C., Pandorfi, H., Almeida, G. L., Giongo, P. R., Pedrosa, E. M., \& Guiselini, C. (2009). Avaliação do conforto térmico e desempenho de frangos de corte sob regime de criação diferenciado. Revista Brasileira de Engenharia Agrícola e Ambiental, 13(6), 802-808. doi: 10.1590/ S1415-43662009000600020

Oliveira, R. F. M. D., Donzele, J. L., Abreu, M. L. T. D., Ferreira, R. A., Vaz, R. G. M. V., \& Cella, P. S. (2006). Efeitos da temperatura e da umidade relativa sobre o desempenho e o rendimento de cortes nobres de frangos de corte de 1 a 49 dias de idade. Revista Brasileira de Zootecnia, 35(3), 797-803. doi: 10.1590/S1516-35982006 000300023
Rostagno, H. S., Albino, L. F. T., Hannas, M. I., Donzele, J. L., Sakomura, N. K., Perazzo, F. G.,... Brito, C. O. (2017). Tabelas brasileiras para aves e suínos composição de alimentos e exigências nutricionais. Viçosa, MG: UFV, Imprensa Universitária.

Rudkin, C., \& Stewart, G. D. (2003). Behaviour of hens in cages: a pilot study using video tapes: a report for the rural industries research and development corporation. Queensland: Rural Industries Research and Development Corporation.

Schiassi, L., Yanagi, T., Jr., Ferraz, P. F., Campos, A. T., Silva, G. R., \& Abreu, L. H. (2015). Comportamento de frangos de corte submetidos a diferentes ambientes térmicos. Engenharia Agrícola, 35(3), 390396. doi: 10.1590/1809-4430-Eng.Agric. v35n3p390-396/2015 
